\title{
THE CHARACTERISTIC OF ECONOMICALLY IMPORTANT TRAITS OF DAIRY COWS DEPENDING ON TYPE OF BODY CONSTITUTION
}

\author{
Ruslana Stavetska \\ Department of Genetics, Breeding and Selection of Animals \\ Bila Tserkva National Agrarian University \\ 8/1 Soborna sq., Bila Tserkva, Ukraine, 09117 \\ rstavetska@gmail.com \\ Yurii Dynko \\ Institute of Animal Breeding and Genetics nd. a. M. V. Zubets of National Academy of Agrarian \\ Science of Ukraine \\ 1 Pogrebniaka str., Chubynske, Kyiv reg., Ukraine, 08321 \\ yura.dynko@gmail.com
}

\begin{abstract}
This study focuses on research of economically important traits of Ukrainian black-and-white dairy cows with different types of body constitution. The aim of the study was to differentiate dairy cows into constitution types and to identify the best types in terms of growth, exterior, milk productivity and reproductive capacity. The cows were differentiated into low-, mid- and high-capacity types of body constitution. Depending on their type the features of growth, exterior, milk productivity and reproduction capacity of primiparous have been studied.

It has been established, that the intensity of growth of heifers from birth to 18 months depended on the type of their body constitution. Higher live weight, absolute and average daily gains were characteristic of heifers with low-capacity body constitution. Their live weight at the age of 18 months on average was $388.5 \mathrm{~kg}$, it was on $30.9 \mathrm{~kg}$ and $60.3 \mathrm{~kg}(\mathrm{P}<0.01)$ more than live weight of mid- and high-capacity heifers. The advantages of low-capacity heifers in average daily gain during the growing period were $60 \mathrm{~g}$ and $117 \mathrm{~g}$, respectively.

The results of the exterior evaluation have shown that primiparous with the high-capacity type of body constitution had greater size and larger measurements primarily of the chest and barrel $(\mathrm{P}<0.05-0.001)$. The higher values of linear evaluation were also observed in cows with the high-capacity type, which were characterized by well-developed chest, wide rump, desired rear view of rear legs, firm udder attachment and strong central ligament. The power of influence of the type of body constitution on linear type traits ranged from $0.5 \%$ (rear teat placement) to $46.2 \%$ (chest width).

Higher milk productivity was a characteristic of mid-capacity cows (an advantage of 305-d milk yield - 340-662 kg, milk fat yield - 9.0-21.0 kg, milk protein yield $-9.8-19.8 \mathrm{~kg}$ ). The best results of reproduction capacity have been observed in cows with the high-capacity type of body constitution (calving percentage $-87.5 \%$ ).

Keywords: dairy cows, type of body constitution, growth, exterior, milk productivity, reproductive capacity.
\end{abstract}

DOI: $10.21303 / 2504-5695.2021 .001696$

\section{Introduction}

Until recently, the most important traits for dairy cows were considered milk yield and milk composition [1]. However, one-sided selection for high yield has led to decrease the resistance of animals to disease, deterioration in reproductive performance and reduction of productive life of dairy cows [2,3]. Nowadays the range of interest of milk producers has significantly expanded and the selection process takes into account reproductive traits, live weight, exterior, longevity, health of animals etc. Exterior as well as body constitution belong to the functional traits, they are elements of selection indices worldwide. Their share in the most widespread indices varies from 17 to $40 \%$ [4-6]. The importance of studying the body constitution is that only animals with good constitution can be healthy, high producing, they have a high level of reproductive performance and longevity. Taking into account the types of body constitution in the selection process contributes to more objective and informative assessment of dairy cows. 
Numerous studies of scientists were devoted to the types of body constitution. Their teachings were based to the ratio of tissues and organs in the body of animals [7], the intensity of the redox processes and gas exchange[8], the adaptability of species [9], the density of the animal body [10], the Golden Ratio of Pythagorean [11] etc.

For evaluation of the body constitution of dairy cattle, the shape of chest and its cross-sectional area was assessed [12]. Later this method was developed and it was proposed to assess the capacity of the thoracic cage [13]. Three types of body constitution was identified - with large medium and small volume. This method of determining the body constitution was further developed. The aim of this research was in developing a fundamentally new method of differentiation of dairy cows into low-, mid- and high-capacity types. The author proposed to determine the type of body constitution as a ratio of thoracic conditional capacity and live weight and he called it - the capacity-weight coefficient [14]. It was proposed to implement the capacity-weight coefficient into linear evaluation of dairy cows, which was recognized by ICAR [15] and was effective from selection and production standpoints.

The research aim was to investigate the economically important traits of dairy cows depending on their body constitution and establish the types of body constitution with the expected rate of growth, exterior, milk productivity and reproduction capacity. In order to achieve this goal primiparous were divided into three types of body constitution and depending on the type their growth, exterior, milk productivity and reproduction capacity have been studied.

\section{Materials and methods}

The study was carried out on the commercial dairy farm LLC "nd. a. Shchorsa", which located in Kyiv region, Ukraine. The study was conducted in 2016-2018. The farm is rearing more than 1500 dairy cattle of Ukrainian black-and-white dairy breed with 600 lactating cows. The differentiation of cows by types of body constitution included measurements of the chest depth and chest width behind the shoulder blades and last rib, length of the thoracic cage, area of the thoracic cage behind the shoulder blades and last rib, conditional capacity of the thoracic cage and live weight. Individual constitutional characteristics of animals were determined by the integrated capacity-weight coefficient (CWC), which characterized the liters of thoracic capacity per kilogram of live weight [14], $(n=101)$.

$$
C W C=\frac{h \times\left(S_{1}+\sqrt{S_{1} S_{2}}+S_{2}\right)}{L W \times 3,000},
$$

where $C W C$ - capacity-weight coefficient, $\mathrm{L} / \mathrm{kg} ; h$ - length of the thoracic cage, $\mathrm{cm} ; S_{1}$ - cross-sectional area of the thoracic cage behind the shoulder blades, $\mathrm{cm}^{2} ; S_{2}$ - cross-sectional area of the thoracic cage behind the last false rib, $\mathrm{cm}^{2} ; L W$ - liveweight, $\mathrm{kg} ; 3,000$ - a constant value, obtained as a result of mathematical structuring of the formula $(3 \times 1,000)$.

In the studied group of cows $C W C$ was $0.72 \mathrm{~L} / \mathrm{kg}$. Cows were divided into three types of body constitution based on the deviation $C W C 0.67 \sigma$ : low-capacity type $(n=26, C W C=0.67 \mathrm{~L} /$ $\mathrm{kg}$ or less), mid-capacity type $(n=52, C W C=0.68-0.75 \mathrm{~L} / \mathrm{kg})$ and high-capacity type ( $n=23$, $C W C=0.76 \mathrm{~L} / \mathrm{kg}$ or more).

The intensity of growth of repair heifers was estimated by live weight, absolute growth rate and average daily gain from birth to 18 months. The exterior of cows with different types of body constitution was assessed through body measurements and linear evaluation. Milk productivity of primiparous (milk yield, fat content and protein content in milk, milk fat yield, milk protein yield, duration of lactation, milk yield per day of lactation) was estimated for 305-day and per lactation. Reproduction capacity of cows was studied by age and weight at first mating and first calving, days open, calving interval, services per conception and calving percentage.

Statistical analyses were performed using Microsoft Excel 2010. 


\section{Discussion of research results}

It has been found, that the biggest newborn heifers had the high-capacity type of body constitution, but the highest live weight from birth to the age of 18 months was characterized for heifers with the low-capacity type. The live weight of low-capacity heifers at 18 months was by $30.9 \mathrm{~kg}(P<0.05)$ and $60.3 \mathrm{~kg}(P<0.01)$ more than the live weight of mid- and high-capacity heifers (Table 1).

Heifers with the low-capacity body constitution in the period of 0-3.0 months had by $6.4 \mathrm{~kg}$ higher absolute growth rate compared to the other types, in the period of 3.1-6.0 months - 3.2$4.0 \mathrm{~kg}, 6.1-9.0$ months $-2.7-8.2 \mathrm{~kg}, 9.1-12.0$ months $-3.9-11.9 \mathrm{~kg}, 12.1-15.0$ months $-8.1-15.6 \mathrm{~kg}$, $15-18$ months $-8.1-17.3 \mathrm{~kg}$. For average daily gain there was a trend similar to the absolute growth rate: the highest value was shown by the animals with the low-capacity type, the lowest - by animals with the high-capacity type of body constitution. The average daily gain of heifers with the low-capacity type from birth to 18 months was $657 \mathrm{~g}$, mid-capacity - $597 \mathrm{~g}$, high-capacity type $540 \mathrm{~g}$. Depending on growing periods, heifers with the low-capacity type of body constitution had an advantage in average daily gain over animals of the same age with the high-capacity type by 71-193 g, and with age the differences have been increased. The average daily gain of heifers with the low-capacity type was 29-90 g higher compared to the mid-capacity type.

Table 1

Growth rate of repair heifers with different types of body constitution, $\mathrm{x} \pm \mathrm{S} . \mathrm{E}$

\begin{tabular}{|c|c|c|c|c|}
\hline \multirow{2}{*}{\multicolumn{2}{|c|}{ Parameters }} & \multicolumn{3}{|c|}{ Type of body constitution } \\
\hline & & low-capacity & mid-capacity & high-capacity \\
\hline \multicolumn{2}{|c|}{ Birth weight, kg } & $33.5 \pm 0.74$ & $35.0 \pm 0.43$ & $36.6 \pm 0.48$ \\
\hline \multirow{6}{*}{$\begin{array}{c}\text { Absolute growth rate } \\
\text { during periods, } \mathrm{kg}\end{array}$} & $0-3.0$ & $50.7 \pm 1.86$ & $44.3 \pm 1.80$ & $44.3 \pm 3.41$ \\
\hline & $3.1-6.0$ & $59.9 \pm 3.29$ & $56.7 \pm 2.36$ & $55.9 \pm 4.71$ \\
\hline & $6.1-9.0$ & $62.3 \pm 2.84$ & $59.6 \pm 2.38$ & $54.1 \pm 4.69$ \\
\hline & $9.1-12.0$ & $64.9 \pm 3.18^{*}$ & $61.0 \pm 2.70$ & $53.0 \pm 4.17$ \\
\hline & $12.1-15.0$ & $61.1 \pm 3.34 * *$ & $53.0 \pm 2.01$ & $45.5 \pm 3.09$ \\
\hline & $15.1-18.0$ & $56.1 \pm 3.92 * *$ & $48.0 \pm 2.13$ & $38.8 \pm 3.72$ \\
\hline \multicolumn{2}{|c|}{ Live weight at 18 months, $\mathrm{kg}$} & $388.5 \pm 11.76^{* *}$ & $357.6 \pm 9.38$ & $328.2 \pm 17.01$ \\
\hline
\end{tabular}

Note: ${ }^{* *} P<0.01$; ${ }^{*} P<0.05$, level of significance compared to the high-capacity type

It has been claimed, that the higher live weight of newborn heifers, the higher their growth rate, and cows with higher live weight were characterized by higher milk productivity. In our study mixed results were obtained. In particular, newborn heifers with the low-capacity type of constitution had less live weight compared to heifers with the mid- and high-capacity types but at the age of 18 months heifers with the low-capacity type had an advantage in live weight [16, 17].

The optimal average daily gain of heifers from birth to the age of first mating was considered not less than $500 \mathrm{~g}$ [18] and $830 \mathrm{~g}$ at the age of 10-15 months [19, 20]. In our study the average daily gain from birth to 18 months exceeded $500 \mathrm{~g}$, but at10-15 months was less than recommended $[19,20]$ and ranged from $506 \mathrm{~g}$ to $721 \mathrm{~g}$ depending on the type of body constitution.

Features of economically important traits of dairy cows, differentiated by the types of body constitution with $C W C$, were studied by the author of the method. The results of our research partially coincided with the data, provided earlier [21]. In particular, he reported the higher live weight at birth by $2.5 \mathrm{~kg}(\mathrm{P}>0.95)$ in heifers with the low- and mid-capacity types of body constitution. In our study higher live weight was observed in newborn heifers with the high-capacity type.

Analyses of linear evaluation of cows with different types of body constitution on a 9-point scale have shown that animals with the high-capacity type compared to the low-capacity type had greater size, they were taller $(+0.8$ point), more width of chest $(+1.7)$ and depth of barrel $(+0.8)$, wider in the rump $(+0.5)$, they had more correct shape of rear legs $(+0.8, \mathrm{P}<0.05)$, stronger fore and rear udder attachment $(+0.4, \mathrm{P}<0.05$ and +0.9 , respectively), stronger central ligament $(+0.8, \mathrm{P}<0.05)$ and longer teats $(+0.5$ point) (Table 2$)$. 
Table 2

Linear evaluation of dairy cows with different types of body constitution on a 9-point scale, $x \pm S$.E

\begin{tabular}{|c|c|c|c|}
\hline \multirow{2}{*}{ Linear type trait } & \multicolumn{3}{|c|}{ Type of body constitution } \\
\hline & low-capacity & mid-capacity & high-capacity \\
\hline Stature & $4.5 \pm 0.36$ & $4.8 \pm 0.26$ & $5.3 \pm 0.44$ \\
\hline Chest width & $4.5 \pm 0.20$ & $5.5 \pm 0.13$ & $6.2 \pm 0.21$ \\
\hline Body depth & $7.3 \pm 0.17$ & $7.5 \pm 0.11$ & $8.1 \pm 0.14$ \\
\hline Angularity & $5.9 \pm 0.28$ & $5.9 \pm 0.18$ & $5.7 \pm 0.28$ \\
\hline Rump angle & $6.3 \pm 0.25$ & $6.2 \pm 0.16$ & $6.4 \pm 0.22$ \\
\hline Rump width & $6.9 \pm 0.19$ & $7.2 \pm 0.16$ & $7.4 \pm 0.21$ \\
\hline Rear legs set & $4.9 \pm 0.22$ & $4.7 \pm 0.14$ & $4.9 \pm 0.28$ \\
\hline Rear legs rear view & $4.4 \pm 0.21$ & $4.6 \pm 0.14$ & $5.2 \pm 0.21^{*}$ \\
\hline Foot angle & $4.7 \pm 0.26$ & $4.7 \pm 0.12$ & $4.8 \pm 0.28$ \\
\hline Fore udder attachment & $4.4 \pm 0.10$ & $4.2 \pm 0.09$ & $4.8 \pm 0.19 *$ \\
\hline Rear udder height & $5.2 \pm 0.36$ & $5.3 \pm 0.24$ & $6.1 \pm 0.31$ \\
\hline Central ligament & $5.8 \pm 0.23$ & $6.1 \pm 0.19$ & $6.6 \pm 0.23 *$ \\
\hline Udder depth & $5.1 \pm 0.33^{*}$ & $4.7 \pm 0.21$ & $4.0 \pm 0.26$ \\
\hline Front teat placement & $5.3 \pm 0.36$ & $5.5 \pm 0.23^{*}$ & $5.4 \pm 0.36$ \\
\hline Rear teat placement & $4.7 \pm 0.21$ & $4.7 \pm 0.19$ & $4.9 \pm 0.23$ \\
\hline Teat length & $5.3 \pm 0.21$ & $5.8 \pm 0.12$ & $5.8 \pm 0.13$ \\
\hline Body condition score & $5.5 \pm 0.20 *$ & $4.8 \pm 0.22$ & $4.8 \pm 0.25$ \\
\hline
\end{tabular}

Note: ${ }^{*} P<0.05$, level of significance compared to the lowest value

Simultaneously, cows with the low-capacity type had a deeper udder $(P<0.05)$ and higher body condition score $(P<0.05)$. The development of linear type traits of cows with the mid-capacity type of body constitution usually has taken an intermediate position between the low- and high-capacity types.

The strength and direction of relationship between the types of body constitution and linear type evaluation of dairy cows depended on the type of constitution and linear type trait. The correlation between them ranged from -0.22 to 0.58 . There was a strong correlation between the type of body constitution and chest width $(r=0.58, P<0.001)$, body depth $(r=0.48, P<0.001)$; medium correlation - with rear legs set $(r=0.30, P<0.01)$, central ligament $(r=0.26, P<0.05)$, teat length $(r=0.25, P<0.05)$ and udder depth $(r=-0.22, P<0.05)$. It should also be noted the correlation between the type of body constitution and stature $(r=0.17)$ and rump width $(r=0.19)$. The power of influence of the types of constitution on linear type traits ranged from $\eta_{x}^{2}=0.5 \%$ (rear teat placement) to $\eta_{x}^{2}=46.2 \%$ (chest width).

The analyses of milk productivity of primiparous with different types of body constitution had shown the advantage of cows with the mid-capacity type in 305-d milk yield, milk fat yield and milk protein yield. Their advantage compared to the low- and high-capacity types in $305-\mathrm{d}$ milk yield was $340 \mathrm{~kg}$ and $662 \mathrm{~kg}$, respectively, milk fat yield $-9.0 \mathrm{~kg}$ and $21.0 \mathrm{~kg}$, milk protein yield $9.8 \mathrm{~kg}$ and $19.8 \mathrm{~kg}$ (Table 3).

Table 3

Milk productivity of primiparous with different types of body constitution, $x \pm S$.E.

\begin{tabular}{cccc}
\hline Parameters & \multicolumn{3}{c}{ Type of body constitution } \\
\cline { 2 - 4 } & low-capacity & mid-capacity & high-capacity \\
\hline Duration of lactation, days & $404 \pm 23.5$ & $387 \pm 16.0$ & $358 \pm 25.9$ \\
305-d milk yield, kg & $7,055 \pm 288.6$ & $7,395 \pm 205.7$ & $6,733 \pm 357.6$ \\
Milk yield per lactation, kg & $9,338 \pm 782.6$ & $9,239 \pm 540.4$ & $7,800 \pm 704.5$ \\
Fat content in milk, \% & $3.52 \pm 0.013^{*}$ & $3.48 \pm 0.007$ & $3.51 \pm 0.010^{*}$ \\
Milk fat yield, kg & $328.7 \pm 17.09^{*}$ & $321.6 \pm 18.33^{*}$ & $273.7 \pm 13.51$ \\
Protein content in milk, \% & $3.11 \pm 0.004$ & $3.10 \pm 0.003$ & $3.11 \pm 0.004$ \\
Milk protein yield, kg & $290.7 \pm 14.34^{*}$ & $286.3 \pm 10.62^{*}$ & $242.7 \pm 12.97$ \\
Milk yield per day of lactation, $\mathrm{kg}$ & $23.1 \pm 0.85$ & $23.9 \pm 0.73$ & $21.8 \pm 1.17$
\end{tabular}

Note: ${ }^{*} P<0.05$, level of significance compared to the lowest value 
Prolonging lactation of cows with the low-capacity type has led to higher milk yield per lactation, milk fat yield and milk protein yield. The milk yield per lactation of cows with the low-capacity type of body constitution compared to the high-capacity type was $1538 \mathrm{~kg}$ higher, milk fat yield $-55.0 \mathrm{~kg}(P<0.05)$, milk protein yield $-48.0 \mathrm{~kg}$ higher $(P<0.05)$. Cows with the mid-capacity type have also significantly prevailed over animals with the high-capacity type in milk yield per lactation $(+1439 \mathrm{~kg})$, milk fat yield $(+47.9 \mathrm{~kg}, P<0.05)$ and milk protein yield $(+43.6 \mathrm{~kg}, P<0.05)$. More objectively the milk yield per day of lactation has shown the efficiency of milk production. Given this trait, cows with the mid-capacity type of body constitution have shown higher efficiency of milk production. Their milk yield per day of lactation was $23.9 \mathrm{~kg}$ that was 0.8 more compared to the low-capacity type and $2.1 \mathrm{~kg}$ more compared to the high-capacity type.

It was found, that the higher milk productivity was observed in cows with the high-capacity type of body constitution [22]. The advantage of Holstein cows with the high-capacity type compared to the low-capacity type in 305 -d milk yield was $1718 \mathrm{~kg}$, milk fat yield $-64.84 \mathrm{~kg}$, milk protein yield $-55.26 \mathrm{~kg}(P>0.999$ in all cases). In our study Ukrainian black-and-white dairy cows with the mid-capacity type of body constitution have prevailed in 305-d milk productivity. The higher milk yield per lactation, milk fat yield and milk protein yield have been shown by cows with the low-capacity type of body constitution. Milk per day of lactation of cows with the mid-capacity type was $23.9 \mathrm{~kg}$, low-capacity - $23.1 \mathrm{~kg}$, high-capacity type $-21.8 \mathrm{~kg}$.

The influence of body constitution type of primiparous on traits of milk productivity ranged from 2.4 to $34.8 \%$ and it was significant for milk yield $\left(\eta_{x}^{2}=24.5 \%, P<0.05\right)$, milk fat yield $\left(\eta_{x}^{2}=34.8 \%, P<0.01\right)$ and milk protein yield $\left(\eta_{x}^{2}=26.0 \%, P<0.05\right)$.

It has been reported, that cows with higher average daily gain had prevailed in milk yield over animals with lower growth intensity [17]. The difference between them for the first lactation milk yield was $1093.0 \mathrm{~kg}$ or $28.06 \%$ ( $>>0.999)$. The statement that animals with higher growth rate were characterized by higher milk productivity has not been confirmed in our study. If higher growth rate were observed in cows with the low-capacity type of body constitution, the highest $305-d$ milk yield was shown by primiparous with the mid-capacity type.

In our study we found some differences in the traits of reproduction capacity depending on the type of body constitution. The youngest age at first mating was typical for cows with the mid-capacity type of body constitution - 15.9 months, that was 2.8 months less compared to the high-capacity type $(\mathrm{P}<0.05)$ (Table 4$)$.

Table 4

Reproduction capacity of primiparous with different types of body constitution, $x \pm$ S.E.

\begin{tabular}{cccc}
\hline Parameters & \multicolumn{3}{c}{ Type of body constitution } \\
\cline { 2 - 4 } & low-capacity & mid-capacity & high-capacity \\
\hline Age at first mating, months & $17.0 \pm 0.58$ & $15.9 \pm 0.58$ & $18.7 \pm 1.16^{*}$ \\
Live weight at first mating, kg & $367.4 \pm 12.95^{* *}$ & $313.7 \pm 6.70$ & $320.6 \pm 9.02$ \\
Age at first calving, months & $26.3 \pm 0.55$ & $26.3 \pm 0.67$ & $28.8 \pm 1.33$ \\
Live weight at first calving, kg & $503.0 \pm 6.30^{* *}$ & $474.5 \pm 5.17$ & $452.1 \pm 7.95$ \\
Days open & $183 \pm 23.4$ & $169 \pm 15.3$ & $140 \pm 25.8$ \\
Calving interval, days & $461 \pm 23.3$ & $444 \pm 15.6$ & $417 \pm 25.7$ \\
Services per conception & $2.0 \pm 0.23$ & $2.2 \pm 0.24$ & $1.8 \pm 0.41$ \\
Calving percentage, $\%$ & $79.1 \pm 3.61$ & $82.2 \pm 2.56$ & $87.5 \pm 2.56$
\end{tabular}

Note: ${ }^{*} P<0.05$, level of significance compared to the lowest value

However, this did not have an impact on the age at first calving, which was the same for cows with the low- and mid-capacity types -26.3 months. This was due to the higher value services per conception in cows with the high-capacity type (2.2), which was 0.2 higher compared to the low-capacity and 0.4 higher - high-capacity types. Since the cows with the low-capacity type of body constitution were characterized by the highest growth rate, their advantage in live weight at first mating and at first calving was evident. Their live weight at first mating was $46.8 \mathrm{~kg}$ and 
$53.7 \mathrm{~kg}$ higher, at first calving $-28.5 \mathrm{~kg}$ and $50.9 \mathrm{~kg}$ higher compared to the high-capacity and mid-capacity types, respectively ( $\mathrm{P}<0.01$ in all cases).

An optimum age of dairy cows at first calving was not considered older than 24 months $[19,20,23]$. The recommended live weight at first mating was about $85 \%$ of adult cows live weight, at which primiparous were characterized by high milk productivity and reproduction capacity. In our study an average age at first calving of primiparous was higher $26.3-28.8$ months with live weight $465-485 \mathrm{~kg}$.

The less days open, shorter calving interval, higher calving percentage were recorded for cows with the high-capacity type of body constitution, the worst value of reproduction capacity traits was inherent to cows with the low-capacity type. Cows with the high-capacity type compared to the low- and mid-capacity types had 43 and 29 days open less, respectively, 44 and 27 days shorter calving interval, 8.4 and $5.3 \%$ higher calving percentage.

Thus, respecting features of cows with different types of body constitution made it possible to optimize the selection process in a herd and to forward it into the required direction. It has been established, that cows with the low-capacity type had the higher live weight from birth to 18 months, higher growth rate and, as a result, higher age and live weight at first calving. Primiparous with the mid-capacity type had the higher 305-d milk productivity and milk yield per day of lactation. Cows with the high-capacity type were of the greater size, they have shown the best results of linear evaluation and reproduction capacity.

\section{Conclusions}

The obtained results of the study can be used in dairy herds to differentiate cows by types of body constitution. Since the type of body constitution of cows is associated with economically important traits (growth, exterior, milk productivity, reproductive capacity), it can be involved into the selection process in a herd, taking into account the desired characteristics of future offspring. The disadvantage of this study is the lack of results of differentiation of mature cows (second, third lactation) on types of body constitution and their relationship with economically important traits. This research has already been conducted and it will be presented in a future publication.

Differentiation of cows depending on the type of body constitution has enabled to identify the features of their growth, development, exterior, milk productivity, reproduction capacity. Taking into account the results could help to optimize the selection process in the herd.

It has been established, that growth intensity of heifers from birth to the age of 18 months depended on the type of body constitution. Higher live weight, absolute growth rate and average daily gain were characteristics of heifers with the low-capacity type. Primiparous with the high-capacity type were bigger, with higher measurements of chest and barrel $(P<0.05-0.001)$. The influence of the low- mid- and high-capacity types of body constitution on the linear type traits ranged from $\eta_{x}^{2}=0.5 \%$ (rear teat placement) to $\eta_{x}^{2}=46.2 \%$ (chest width).

Higher milk productivity was inherent to the cows with the mid-capacity type. The influence of the type of body constitution on milk yield was $\eta_{x}^{2}=24.5 \%(P<0.05)$, milk fat yield $-\eta_{x}^{2}=34.8 \%$ $(P<0.01)$, milk protein yield $-\eta_{x}^{2}=26.0 \%(P<0.05)$. Better reproductive performance was observed in cows with lower milk productivity- high-capacity type (calving percentage $-87.5 \%$ ).

\section{References}

[1] Prata, M. A., Faro, L. E., Moreira, H. L., Verneque, R. S., Vercesi Filho, A. E., Peixoto, M. G. C. D., Cardoso, V. L. (2015). Genetic parameters for milk production traits and breeding goals for Gir dairy cattle in Brazil. Genetics and Molecular Research, 14 (4), 12585-12594. doi: https://doi.org/10.4238/2015.october.19.2

[2] Samoré, A. B., Rizzi, R., Rossoni, A., Bagnato, A. (2010). Genetic parameters for functional longevity, type traits, SCS, milk flow and production in the Italian Brown Swiss. Italian Journal of Animal Science, 9 (2). doi: https://doi.org/10.4081/ijas.2010.e28

[3] Oltenacu, P. A., Broom, D. M. (2010). The impact of genetic selection for increased milk yield on the welfare of dairy cows. Animal Welfare, 19 (S), 39-49. Available at: https://www.researchgate.net/publication/228675305_The_impact_of_genetic_ selection_for_increased_milk_yield_on_the_welfare_of_dairy_cows

[4] Updates to the Total Performance Index (TPI) and type composites. Holstein Pulse. Available at: http://www.holsteinusa.com/ pdf/Upcoming_Changes_aug17.pdf 
[5] Nordic Total Merit Index. VikingGenetics. Available at: https://www.vikinggenetics.com/about-us/ntm/ntm-unlocked?show=anvp

[6] Pro\$ \& LPI: Enhancements and Updates (2019). Canadian Dairy Network. Available at: https://www.cdn.ca/document.php?id=516

[7] Kuleshov, P. N. (1937). Vybor po ekster'eru loshadey, skota, ovets, sviney. Moscow: Sel'hozgiz, 202.

[8] Dyurst, I.; Kalmanson, S. Ya. (Ed.) (1936). Osnovy razvedeniya krupnogo rogatogo skota. Moscow: Sel'hozgiz, 455.

[9] Savchuk, D. I., Polupan, Yu. P. (1989). Otsenka konstitutsii sel'skohozyaystvennyh zhivotnyh. Zootehniya, 4, 19-23.

[10] Shalimov, M. O. (1996). Teoretychni i praktychni aspekty formuvannia typiv konstytutsiyi chervonykh porid khudoby. Kharkiv, 39.

[11] Siratskyi, Y., Merkushyn, V., Fedorovych, Ye. (2001). Konstytutsiya velykoi rohatoi khudoby yak mira harmonii budovy tila. Propozytsiya, 12, 82-84.

[12] Pogodaev, S. F. (1963). Sravnitel'naya harakteristika biologicheskih i produktivnyh osobennostey korov simmental'skoy porody raznyh tipov konstitutsii. Moscow, 26.

[13] Panasiuk, I. M. (1996). Produktyvni y tekhnolohichni yakosti koriv zalezhno vid konstytutsiyi, vyshchoi nervovoi diyalnosti, stresostiykosti ta oznak rannoho ontohenezu. Dnipropetrovsk, 293.

[14] Chernenko, O. M. (2015). Pat. No. 97878 UA. Sposib vyznachennia typu konstytutsiyi u koriv za obiemno-vahovym koefitsientom. No. u201410996; declareted: 08.10.2014; published: 10.04.2015, Bul. No. 7.

[15] ICAR: The Global Standard for Livestock Data. Available at: https://www.icar.org/

[16] Van De Stroet, D. L., Calderón Díaz, J. A., Stalder, K. J., Heinrichs, A. J., Dechow, C. D. (2016). Association of calf growth traits with production characteristics in dairy cattle. Journal of Dairy Science, 99 (10), 8347-8355. doi: https://oi.org/10.3168/ jds.2015-10738

[17] Prishedko, V. M., Lesnovskay, E. V., Karlova, L. V., Dutka, V. R. (2017). Economic efficiency of the use of using the first-born cows of Holstein breed with different intensity of their formation in early ontogenesis. Scientific Messenger of Lviv National University of Veterinary Medicine and Biotechnologies, 19 (79), 163-168.

[18] Tulinova, O. V., Vasil'eva, E. N., Egiazaryan, A. V., Solovey, V. B. (2011). Molochnaya produktivnost' ayrshirskih pervotelok $\mathrm{v}$ zavisimosti ot intensivnosti ih rosta $\mathrm{v}$ raznye periody vyraschivaniya. Zootehniya, 8, 2-4.

[19] Serjsen, K. (2005). Mammary development. Calf and heifer rearing: principles of rearing the modern dairy heifer from calf to calving. Nottingham: Nottingham University Press, 237-251.

[20] Storli, K. S., Klemetsdal, G., Volden, H., Salte, R. (2017). The relationship between Norwegian Red heifer growth and their first-lactation test-day milk yield: A field study. Journal of Dairy Science, 100 (9), 7602-7612. doi: https://doi.org/10.3168/ jds.2016-12018

[21] Chernenko, O. M. (2015). Formuvannia eksterieru i konstytutsiyi u koriv ukrainskoi chervonoi molochnoi porody. Visnyk Dnipropetrovskoho derzhavnoho ahrarno-ekonomichnoho universytetu, 3 (37), 88-90.

[22] Chernenko, O. M. (2015). Milk productivity of holstein breed cows of different somatotypes. Naukovyi visnyk «Askaniya-Nova», 8, 104-114.

[23] Tozer, P. R., Heinrichs, A. J. (2001). What Affects the Costs of Raising Replacement Dairy Heifers: A Multiple-Component Analysis. Journal of Dairy Science, 84 (8), 1836-1844. doi: https://doi.org/10.3168/jds.s0022-0302(01)74623-1

Received date 09.02.2021

(C) The Author(s) 2021

Accepted date 19.03.2021

Published date 31.03.2021

This is an open access article under the CC BY license (http://creativecommons.org/licenses/by/4.0).

How to cite: Stavetska, R., Dynko, Y. (2021). The characteristic of economically important traits of dairy cows depending on type of body constitution. EUREKA: Life Sciences, 2, 9-15. doi: https://doi.org/10.21303/2504-5695.2021.001696 